\title{
Challenges to Curriculum Implementation: Reducing the Gap between the Aspired and its Implementation through Change Management
}

\author{
$\mathrm{Ng}$ Soo Boon \\ Curriculum Development Division, Ministry of Education, Malaysia
}

\begin{abstract}
How to cite
Ng, S. B. (2018). Challenges to Curriculum Implementation: Reducing the Gap between the Aspired and its Implementation through Change Management. Asia Pacific Journal on Curriculum Studies, 1(1), 14-19. https://doi.org/10.53420/apjcs.2018.3
\end{abstract}

\begin{abstract}
The development of school curriculum in many countries is still very centralized. The National School Curriculum as a program of learning is a highly sensitive document as it contains the aspiration of the nation, preparing its citizen to face future challenges. It is a document of hope. However, much of the excitement during the adoption of the curriculum documents has diminished and has been replaced by disappointment in the implementation stage, as there are gaps between the aspiration and the actual implementation. These gaps are inevitable as there is no perfect system that ensures seamless coordination between the different sectors involved. Often, there is a problem with the orchestration of a large-scale systemic change, and a failure to deliberate human factors sufficiently. This paper looks into the various factors influencing curriculum implementation, especially looking at it as a change process.
\end{abstract}

Keywords: curriculum implementation, change management in curriculum implementation

\section{Introduction}

Effective curriculum implementation is crucial for the success of any curriculum innovation; it is the real test of the change. However, in many cases, research indicated that much of what is planned does not get implemented (National Institute for Educational Research of Japan [NIER], 1999; Nor Puteh, 1994; Ornstein \& Hunkins, 1993; Siti Hawa, 1986). This is not surprising as curriculum implementation entails extensive and concerted involvement of many stakeholders. It often requires restructuring habits, reforming thoughts, and deeper conceptual understanding of instructional methodology among the implementers. This takes time and much planning. Existing literature on curriculum implementation looks at the issue from two perspectives, curriculum implementation as instruction and curriculum implementation as a change process.

\section{Curriculum Implementation as Classroom Instruction}

The first perspective on curriculum implementation equates it with instruction, or the actual teaching and learning that happened in the class. It is the engagement of learners with the curriculum and the planned learning opportunities (Fullan \& Pomfret, 1977; Macdonald, 1965; Saylor, Alexander, \& Lewis 1981). It is the implementation of the curriculum plan (Saylor \& Alexander, 1974). Fullan \& Pomfret (1977) asserted that "implementation is not simply an extension of planning and adoption processes, it is a phenomenon in its own right" (p. 336). Curriculum experts holding this school of thought thus contemplate on issues of planning of instruction, teacher's behavior, and teaching models. The scope is confined to the lessons conducted by teachers, a result of teacher's implementation of the curriculum in the classroom.

Instructional plans are made as a result of the second level of curriculum development (Remillard, 1999) where the teacher deliberates on the curriculum documents, and adapts or translates them into classroom activities appropriate to the students. This level of curriculum development is where teachers link their understanding of the curriculum to their practice, transforming curriculum plan into instruction. What influences the decision and choice teachers made at this point of pre-instructional planning? Saylor et al. (1981) suggested the 'screens' given in Figure 1. Cronin-Jones's (1991) study on science teachers discovered the 'screens' as beliefs about how students learn, the teacher's role in the classroom, the ability levels of students, and the relative importance of content topics. Ng's $(2010,2013,2015)$ study on the implementation of the Malaysian thinking curriculum found the 'screens' as personal characteristics, conceptions of a thoughtful classroom, and the role they played in their 
classroom. In the process of translating curriculum into actual classroom instruction, teachers have been found to consciously or subconsciously consider factors such as these 'screens' in making curriculum decisions. Thus, there is a need to identify these factors in each country to understand and predict the success of curriculum implementation.

A: Community values and expectations

B: Pupil needs, interests, capabilities, role in planning

C: Educational environment - class organisation, materials, administrative support and constraints

D: Teacher's final decision on an appropriate instructional plan

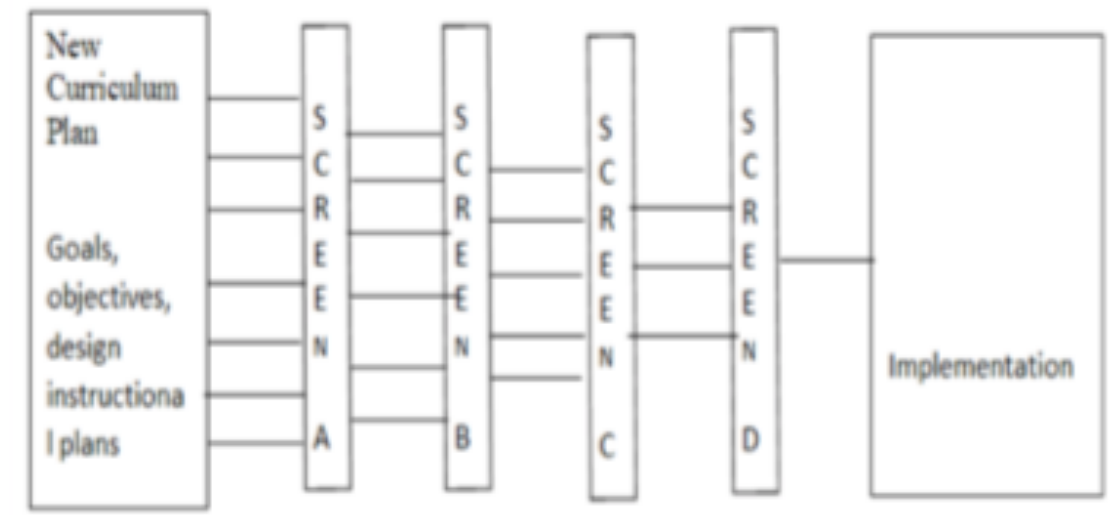

Figure 1. A Rational Static Model for Linking a Curriculum Plan and Instruction. Adapted from Curriculum planning for better teaching and learning (4th ed.), by J.G. Saylor, W.M. Alexander, and J.J. Lewis, 1981, p. 261. Copyright 1981 by Holt, Rinehart and Winston.

\section{Curriculum Implementation as a Change Process}

The second perspective on curriculum implementation is that of a change process. Various terms have emerged such as putting the curriculum to work (Beauchamp, 1975), implementing curriculum change (Armstrong, 1989), and curriculum improvement (Tanner \& Tanner, 1995). Following this perspective, acceptance of change, change agents, commitment to change, and the roles of stakeholders are the focus. The orientation is towards management of change.

Among factors that contribute to the success of change is the commitment of the stakeholders towards this change. Beauchamp (1975) specifically relates it to the "commitment of teachers to use the curriculum as a point of departure for the development of instructional strategies" (p. 165). One interesting barrier to this commitment is teachers' fear of interference and imposition onto their autonomy in deciding the teaching strategies they think are appropriate to their students (Beauchamp, 1975). Beauchamp (1975) proposed that curriculum planners consciously create more flexible curriculum design and institute realistic implementation procedure to counter this fear. Teachers' inputs are crucial in creating such realistic design and procedures. One effective method is to involve teachers in the process of curriculum development. Beauchamp (1975) reported that there is a significant relationship between teachers' participation in curriculum development and their implementation of the curriculum. Teachers' willingness to participate should not be taken for granted; teachers need to be motivated to implement changes in curriculum.

Teachers' motivation is another major component in curriculum implementation as a change process (Makewa \& Ngussa, 2015). Makewa and Ngussa (2015) observed that teachers' autonomy and creativity are increasingly being curtailed by control and regulation from the authority and teachers are being asked to do more with less (resources and incentives). Through literature reviews and research findings, Makewa and Ngussa (2015) found that working with children is the main determinant of teacher's job satisfaction. Generally teachers feel motivated when what they do benefits society, and they are able to spend a sufficient proportion of their time working with children. In other words, to motivate teachers to adopt to curriculum change, they need to be convinced that they are contributing towards education at large, and that their contribution will make a difference in the lives of their students.

The identification and deliberation of the stakeholders' role in curriculum implementation is essential in discussing change management. It is important to be aware that there are stakeholders other than school leaders and teachers who are involved in many different ways as curriculum affects them directly or indirectly as shown in Table 1. 
Table 1

Stakeholders in Curriculum Implementation and Their Roles

\begin{tabular}{ll}
\hline Stakeholders & Responsibilities and roles \\
\hline Student / Learner & $\begin{array}{l}\text { Students are the very reason a curriculum is developed; their } \\
\text { active and direct involvement will make or unmake the } \\
\text { curriculum. Thus, the characteristics of students need to be a } \\
\text { consideration in making any curriculum plan. } \\
\text { Teachers interpret the curriculum: they are the designers as well as } \\
\text { decision makers in executing the curriculum. They write lesson } \\
\text { plans or unit plans daily, weekly, or yearly. They prepare activities } \\
\text { for students to do and modify the curriculum to suit to the } \\
\text { learner's characteristics. Teachers need to be motivated to } \\
\text { implement curriculum change. } \\
\text { School principals are the curriculum managers. They play an } \\
\text { important role in shaping the curriculum. They are responsible in } \\
\text { formulation of the school's vision and mission which must be } \\
\text { aligned with the curriculum change. They need to ensure there is } \\
\text { continuity, relevance, and balance in the implementation of the } \\
\text { curriculum. } \\
\text { Effective parental involvement in school affairs is linked to high- } \\
\text { quality educational experiences for the students. Parent } \\
\text { involvement extends from the school to the home, ensuring a } \\
\text { continuity in the philosophy behind the curriculum change. } \\
\text { Community involvement include professional orgnanisations, civil } \\
\text { society, as well as individuals in the community. The community } \\
\text { members can provide expertise, and resources to aid curriculum } \\
\text { implementation. } \\
\text { Gommunity } \\
\text { Government officers include those from the planning, developing, } \\
\text { regulatory, and monitoring departments at various levels. They } \\
\text { need to understand the curriculum change. Often, issues of } \\
\text { curriculum implementation stem from a silo mentality among } \\
\text { these governmental offices. }\end{array}$ \\
\end{tabular}

There is a need to recognize that change does not happen in isolation, as it impacts the whole organization, the whole system. The stakeholders enumerated in Table 1 need to work as a team. Change management focuses on the people who affect the change (Cameron \& Green, 2012) and a structured approach which aims to ensure coordination and coherence. This approach involves having a shared vision; establishing a sense of urgency for change; creating a guiding coalition; developing synergised strategies; communicating the change; empowering action; and, ensuring a more sustainable change in working culture (Kotter, 2012). It is only through this systematic and structured manner that changes can be thoroughly and smoothly implemented. The key idea is to bring stakeholders from the current situation to the new one. In the process, policies and strategies need to be developed and its implementation monitored. However, readiness for change must first be ensured before monitoring and regulatory measures step in. It is only when the people within the organisation make their own personal transitions to adapt and change that the organisation can reap the benefits of change (International Bureau of Education [IBE], 2013; Cameron \& Green, 2012). Leadership need to help and support the people through these individual transitions. Thus, communication plan and identification of change agents is of utmost importance. Success indicators need to be determined and on-going assessment made to adjust each step to ensure success.

\section{Curriculum Implementation as a System}

In ensuring effective curriculum implementation, one need to consider it from the perspective of both instruction and change. Although classroom instruction is the most direct manifestation of curriculum change, one needs to look from a broader and deeper perspective; as instruction changes to be aligned with curriculum change, a sustainable change in teachers' behavior is probably what policy makers desire; a leading edge shift in the way textbooks are written is actually what society requires; and, ultimately, a change in how community and society view education and learning outcomes is the ultimate purpose of the curriculum change. A change of this scale needs engagement with all stakeholders. There is a real need to pay more attention to the process of establishing mechanisms that facilitate change which ultimately support teachers' classroom instruction (IBE, 2013) in a more sustainable manner. This requires us to look upon curriculum as a system (Beauchamp, 1975; Ornstein, 1995; Saylor \& Alexander, 1974). A system consists of a set of interrelated components organised to attain the ends (goals and objectives) for 
which the system is established. With a systems approach, the objectives are always placed in the center of decision-making. A systems approach provides the planners and implementors of the plan with a systematic and comprehensive view of the whole process of curriculum implementation. Beauchamp (1975) described the system as consisting of the "personnel organisation and the organised procedures needed to produce a curriculum, to implement it, to appraise it, and to modify it in light of experience" (p. 59). It involves continuous decision making and actions. Besides the curriculum system, there are many other systems at work in the educational institutions as shown in the Appendix. Each system is essential for the effective running of educational institutions at various levels. The planning and carrying out of these systematic processes is known as curriculum engineering (Beauchamp, 1975; Ornstein \& Hunkins, 1993). Effective curriculum engineering is essential to reduce the gap between the aspired curriculum and the implemented curriculum. This entails establishing a comprehensive long-term plan covering areas of teacher education, resource production and distribution, assessment, professional development, supervision, and monitoring. The role and responsibility of various stakeholders has to be ascertained and action plans have to be drawn up at state, district, and school levels. The important element of coherence and components of interaction between these sub-systems must be put in place so that the silo mentality does not hinder the success of the curriculum implementation.

\section{Challenges in Curriculum Implementation}

Curriculum is a political agreement; it outlines the government's national agenda (IBE, 2013). It is a policy and technical agreement with the people as it consists of the expectations of the society (IBE, 2013). It needs the support of both the government and the people. The urgency of change at times can be overwhelming and thus, insufficient attention is given to managing the change. The time needed for change is largely being ignored. In such instances, curriculum implementation might suffer as the teachers might not be ready for the change, or resources and infrastructure have not been made sufficient. Coherence among the various agencies has not been established, leaving many gaps which may affect the success of curriculum implementation.

National level change will definitely incur huge cost. While private sector may use a substantial portion of its fund, up to $20 \%$ to introduce and spearhead change, the public sector may spend up to only $1 \%$ only of its available resources on change-oriented efforts and in many instances educators might even work overtime without extra pay to adjust to the change (IBE, 2013). This might be one reason for the gap between the aspired curriculum and curriculum implementation.

Successful curriculum implementation often implies a change of habit; in other words, it is a cultural change. Changes involving beliefs and values are difficult to implement. It takes time and persistence. Examples of such change are from teacher-centered to student-centered learning and from a focus on national examinations to school-based assessment. The stakeholders need evidence to convince them of the worthiness of such change and to give them the confidence that this change will produce better outcomes. Often, there is an information gap between policy makers, curriculum developers, curriculum implementers, and society at large. Employing systems management in curriculum implementation is yet another challenge as a silo mentality has been the norm in many administrations. Coordinating and ensuring coherence among the various departments and agencies vertically and horizontally is more difficult than we can anticipate, and yet the success of curriculum implementation is heavily dependent on this coherence. The process of planning, implementing, monitoring, and evaluating various parts of the system necessitates intelligent and sometimes shrewd maneuvering. Vision and objectives must be clear; action plans strategic and thorough; agents of change and leadership identified.

\section{Conclusion}

Change causes unease. This is especially true for changes in education systems which affect many members of society. People generally have a tendency towards conservatism and trying to maintain the status quo. Defensiveness may set in, making it difficult to even initiate the change. The big- gest challenge in education is to convince the huge numbers of implement- ers of the change and to sustain that change. In order to ensure better success of curriculum implementation, we need to look at curriculum implementation as a change process and develop the system to manage the change. For the curriculum implementers to deliver what has been put forth in the curriculum documents carrying the national aspiration, the support system must be in place. It takes a lot of time and effort for there are no shortcuts in curriculum implementation.

\section{References}

Armstrong, D. G. (1989). Developing and documenting the curriculum. Boston: Allyn and Bacon.

Beauchamp, G.A. (1975). Curriculum theory (3rd ed.). Illinois: The KAGG Press. 
Cameron, E., \& Green, M. (2012). Making sense of change management (3rd ed.). Britain: Kogan Page.

Cronin-Jones, L. L. (1991). Science teacher beliefs and their influence on curriculum implementation: Two case studies. Journal of Research in Science Teaching, 28(3), 235-250.

Fullan, M., \& Pomfret, A. (1977). Research on curriculum and instruction implementation. Review of Educational Research, 47(1), 335-397.

International Bureau of Education - United Nations Educational, Scientific and Cultural Organisation \& Ministry of Education Malaysia. (2013). Training tools for curriculum development: A resource pack for gender-responsive STEM education. Geneva: IBE.

Kotter, J. P. (2012). Leading change. Boston: Harvard Business Review Press.

Macdonald, J. B. (1965). Educational models for instruction: Introduction. In J. B. Macdonald \& R. R. Leeper (Eds.), Theories of instruction (pp. 1-7). Washington, D. C.: Association for Supervision and Curriculum.

Makewa, L. N., \& Ngussa, B. M. (2015). Curriculum implementation and teacher motivation: A theoretical framework. In N. P. Ololube, P. J. Kpolovie, \& L. N. Makewa (Eds.), Handbook of research on enhancing teacher education with advanced instructional technologies (pp. 244-258). Pennsylvania: IGI Global.

National Institute for Educational Research of Japan. (1999). An international comparative study of school curriculum. Japan: NIER.

Ng, S. B. (2010). Creating thoughtful classroom, implementation of thoughtful science curriculum by master teachers. Germany: Lambert Academic Publishing.

Ng, S. B. (2013). Creating a best practice of thoughtful chemistry classroom. Malaysia Science and Mathematics Education Journal, 3(2), 106-127.

$\mathrm{Ng}$, S. B. (2015). Conception of thoughtful teaching by four master teachers in Malaysia. The Malaysian Journal of Qualitative Research, 3(1), 44-59.

Nor Puteh, S. (1994). The development and implementation of the Integrated Curriculum for Secondary School (KBSM) in Malaysian secondary schools (Unpublished doctoral dissertation). University of Sussex, United Kingdom.

Ornstein, A. C. (1995). Curriculum, instruction and supervision: Their relationship and the role of the principal. In A. C. Ornstein \& L. S. Behar (Eds.), Contemporary issues in curriculum (pp. 281 287 ). Massachusetts: Allyn and Bacon.

Ornstein, A. C., \& Hunkins, F. P. (1993). Curriculum foundations, principles and issues. Boston: Allyn and Bacon.

Remillard, J. T. (1999). Curriculum materials in Mathematics education reform: A framework for examining teachers' curriculum development. Curriculum Inquiry, 29(3), 315-342.

Saylor, J. G., \& Alexander, W. M. (1974). Planning curriculum for schools. New York: Holt, Rinehart and Winston.

Saylor, J. G., Alexander, W. M., \& Lewis, J. J. (1981). Curriculum planning for better teaching and learning (4th ed.). New York: Holt, Rinehart and Winston.

Siti Hawa, A. (1986). Implementing a new curriculum for primary school, a case study from Malaysia (Unpublished doctoral dissertation). University of London, United Kingdom.

Tanner, D. \& Tanner, L. (1995). Curriculum development: Theory into practice (3rd ed.). New Jersey: Prentice Hall, Inc. 


\section{Appendix}



Adapted from Creating thoughtful classroom, implementation of thoughtful science curriculum by master teachers, by S. B. Ng, 2010, p. 33. Copyright 2010 by Lambert Academic Publishing. 